\title{
The anti-idiotypic antibody 1F7 stimulates monocyte interleukin-10 production and induces endotoxin tolerance
}

\author{
Tigran K Davtyan ${ }^{1}$, David A Poghosyan², Anna G Sukiasyan ${ }^{3}$ and Michael D Grant ${ }^{4^{*}}$
}

\begin{abstract}
Background: Pathogens that establish chronic infection elicit immune responses with suppressive cytokines dominating over pro-inflammatory cytokines. Chronic hepatitis C virus (HCV) infection, human immunodeficiency virus (HIV) infection and simian immunodeficiency virus (SIV) infection are associated with high levels of antiviral antibodies expressing a common idiotype specifically recognized by the 1F7 monoclonal antibody (mAb). The 1F7 $\mathrm{mAb}$ is a murine IgMk antibody raised against immunoglobulin pooled from the plasma of multiple HIV-infected individuals. In this study, we investigated direct effects of the 1F7 mAb itself on peripheral blood mononuclear cells (PBMC).

Methods: Isolated monocytes or PBMC from healthy controls were incubated with the 1F7 mAb or IgMk mAb control. Cytokine production was measured in cell culture supernatants by ELISA and cells producing interleukin-10 (IL-10) were identified by subset depletion and intracellular flow cytometry. Endotoxin tolerance was assessed by exposing monocytes to lipopolysaccharide (LPS) following 1F7 mAb or IgMk mAb control pre-treatment and comparing tumor necrosis factor (TNF)-a levels in cell culture supernatants.

Results: The 1F7 mAb stimulated monocytes and CD36 ${ }^{+}$lymphocytes to produce IL-10 in a time and dosedependent manner. Treatment of monocytes with $1 \mathrm{~F} 7 \mathrm{mAb}$ also reduced their subsequent responsiveness to LPS stimulation.

Conclusions: Induction of antibodies expressing the 1F7 idiotype by chronic pathogens may facilitate IL-10 production and progression to chronic infection. Direct effects of IL-10 from human monocytes stimulated by 1F7-like antibodies, followed by monocyte transition to an alternatively activated phenotype illustrated by endotoxin tolerance, are two complementary features favouring a tolerogenic or non-responsive immunological environment.
\end{abstract}

Keywords: Hepatitis C virus, Monocyte, Interleukin-10, Idiotype, Endotoxin tolerance

\section{Background}

Immunoglobulins contain unique primary sequences that are created by Ig gene rearrangement and further diversified by somatic hypermutation. The integrated composition of immunogenic epitopes within the variable $(\mathrm{V})$ region of a given immunoglobulin (Ig) molecule is designated as its "idiotype" (Id). Anti-idiotypic antibodies reactive against determinants within the $\mathrm{V}$ regions of other antibodies may recognize rare "private" determinants,

\footnotetext{
* Correspondence: mgrant@mun.ca

${ }^{4}$ Division of BioMedical Sciences, Faculty of Medicine, Memorial University of Newfoundland, St. John's, NL, Canada

Full list of author information is available at the end of the article
}

restricted to certain rearranged and modified sequences, or "public" determinants, common to germ-line sequences of components within the V region. Public or common idiotypes not associated with shared germ-line sequences arise through convergent selection processes. Antibodies with common idiotypes, but different antigenic specificity, usually emerge within a setting of chronic immune activation. In some cases, their selection may reflect adaptive exploitation of locally and systemically distributed idiotypic interactions by chronic pathogens $[1,2]$. The antiidiotypic $\mathrm{mAb} 1 \mathrm{~F} 7$ was raised in BALB/c mice injected with immunoglobulin pooled from multiple human immunodeficiency virus (HIV)-infected individuals [3]. The

\section{Biomed Central}


1F7 idiotype is not restricted to any particular Ig heavy chain variable $(\mathrm{VH})$ gene or gene family and occurs on human antibodies against (HIV) and hepatitis $\mathrm{C}$ virus (HCV) and on macaque antibodies against simian immunodeficiency virus (SIV) [4-7]. The 1F7 anti-idiotypic mAb reacts with human antibodies against HIV Env, Gag and Pol proteins, human antibodies against different $\mathrm{HCV}$ proteins and macaque antibodies against different SIV proteins [4-8]. This broad distribution of the 1F7-defined idiotope on parallel sets of antibodies against different chronic pathogens positions it at a common idiotypic convergence point connected to chronic infection or immune activation.

An association between the level of antibodies expressing the 1F7 Id and outcome of infection was recently shown in hepatitis $C$ infection. The level of antibodies reacting with the anti-idiotypic $\mathrm{mAb} 1 \mathrm{~F} 7$ is significantly higher in persons with chronic hepatitis $\mathrm{C}$ infection than in either healthy donors or in persons who spontaneously cleared HCV [9]. The 1F7 Id is also more common on the Ig B cell receptors of $\mathrm{CD}^{+} \mathrm{B} 1 \mathrm{~B}$ cells than on the Ig B cell receptors of CD5 B cells. Since B1 B cells are a source of interleukin-10 (IL-10), we speculated that interactions between $\mathrm{HCV}$ proteins and $\mathrm{B} 1$ $B$ cells that drive production of 1F7 Id-expressing anti-HCV antibodies might also stimulate IL-10 production by $\mathrm{B} 1 \mathrm{~B}$ cells and monocytes during $\mathrm{HCV}$ infection $[10,11]$.

In acute $\mathrm{HCV}$ infection, production of pro-inflammatory TH1-type cytokines by $\mathrm{T}$ cells in response to viral antigens correlates with self-limited infection, while production of TH2-type cytokines heralds chronic infection [12,13]. Similarly, chronic HCV infection is marked by elevated TH2type and reduced TH1-type cytokine responses $[14,15]$. Peripheral TH1-type cytokines rise in parallel with virological responses to interferon-alpha (IFN- $\alpha$ ) therapy $[16,17]$, while TH2-type cytokines fall together with viral load $[18,19]$. The amount of IL-10 induced during acute infection is a critical determinant of progression to chronic infection versus viral clearance in certain animal model systems and induction of IL-10 by HCV proteins has been demonstrated in several in vitro studies [20,21]. Subjects with untreated chronic HCV infection have elevated serum levels of IL-10 and disease association studies of IL-10 promoter polymorphisms indicate that IL-10 levels are important in both susceptibility to infection and resistance to inflammatory disease [22].

Here we studied effects of the anti-idiotypic mAb 1F7 on IL-10 production by normal human peripheral blood monocytes and $\mathrm{CD}^{+} 6^{+}$lymphocytes. We previously showed that $\mathrm{CD}^{+} 6^{+}$lymphocytes (CD14-negative non-T, non-B non-NK cells with lymphocyte forward and side scatter characteristics by flow cytometry) constitutively produce IL-10 and potentially influence homeostatic innate immune suppression [23]. We also studied the influence of 1F7 mAb on IL-10 and tumor necrosis factor- $\alpha$ (TNF- $\alpha)$ production by isolated monocytes activated by toll-like receptor 4 (TLR4) and nuclear oligomerization domain (NOD)-like (agonists), and the influence of 1F7 mAb on monocyte endotoxin tolerance.

\section{Methods}

Influence of $1 \mathrm{F7} \mathrm{mAb}$ on IL-10 production by peripheral blood mononuclear cells (PBMC)

The 1F7 mAb was produced as murine hybridoma culture supernatant with IgM concentration measured by ELISA [7]. Peripheral blood samples were obtained from 10 healthy donors (4 male and 6 female). Approval for this study was obtained from the Ethics Committee of Yerevan State Medical University and informed consent was obtained from all donors. Peripheral blood mononuclear cells (PBMC) were collected by histopaque-1077 (Sigma-Aldrich) gradient centrifugation of whole blood and resuspended in RPMI-1640 medium containing 10\% fetal calf serum (FCS), $5 \mathrm{mM}$ HEPES, $2 \mathrm{mM}$ L-glutamine, $1 \mathrm{mM}$ sodium pyruvate, $100 \mathrm{U}$ penicillin, and $100 \mu \mathrm{g}$ streptomycin $/ \mathrm{ml}$ (all from Invitrogen). $2.5 \times 10^{6} \mathrm{PBMC}$ were treated with $0.48-1.92 \mu \mathrm{g} / \mathrm{ml} \mathrm{mAb} 1 \mathrm{~F} 7$ by two-fold dilution of 1F7 hybridoma supernatant or with an IgMk $\mathrm{mAb}$ control (eBioscience) at equivalent IgM concentrations. The endotoxin content in 1F7 hybridoma supernatant or IgMk control was determined by Limulus Amebocyte Lysate assay (Pyrogent, Lonza), with detection limit $0.03 \mathrm{EU} / \mathrm{ml}$, as per the manufacturer's recommendations. Cells were incubated for 24, 48 and $72 \mathrm{~h}$ with $1 \mathrm{~F} 7$ $\mathrm{mAb}$ or IgMк control at $37^{\circ} \mathrm{C}$ with $5 \% \mathrm{CO}_{2}$. After incubation, cells were pelleted by centrifugation and the supernatants collected and stored at $-80^{\circ} \mathrm{C}$ until cytokines were measured. The amount of IL-10 in supernatants was determined as per the manufacturer's instructions by ELISA using the human IL-10 Ready-SET-Go test kit (eBioscience) with a detection limit of $2 \mathrm{pg} / \mathrm{ml}$.

\section{Influence of 1F7 mAb on IL-10 production by purified monocytes}

Peripheral blood monocytes were isolated by adherence of isolated PBMCs to $25 \mathrm{~cm}^{2}$ plastic flasks for $45 \mathrm{~min}$ at $37^{\circ} \mathrm{C}$ in $6 \% \mathrm{CO}_{2}$ [24]. Adherent monocytes were washed three times with endotoxin-free PBS and cultured at $5 \times 10^{5}$ cells $/ \mathrm{ml}$ in complete medium. Lipopolysaccharide (LPS) from $E$. coli $026: B 6$ at $100 \mathrm{ng} / \mathrm{ml}$ or $2.5 \mu \mathrm{g} / \mathrm{ml}$ peptidoglycan (PGN), a NOD1 and NOD2 ligand, from E. coli 0111:B4 (both from Invivogen) were included in the culture media from day 0 to day 3 . Cell free supernatants collected at days 1 and 3 were stored at $-80^{\circ} \mathrm{C}$ until IL-10 was measured. Monocytes were depleted from PBMC using EasySep ${ }^{\circledR}$ human CD14 magnetic nanoparticles (Stemcell) according to the manufacturer's instructions. The purity of positively 
selected monocytes, as assessed by cell surface staining with fluorescein isothiocyanate (FITC)-conjugated anti-CD14 (eBioscience, clone 61D3, IgG1א) and flow cytometry, ranged from $97.5-98.3 \%$.

\section{Intracellular and cell surface staining of monocytes and lymphocytes}

After PBMC incubation with the $1 \mathrm{~F} 7 \mathrm{mAb}, 5 \times 10^{5}$ cells were surface stained with either $0.3 \mu \mathrm{g}$ (FITC)-conjugated anti-CD36 (Serotec, clone SMO, IgM), anti-CD14-FITC or isotype-matched controls for $30 \mathrm{~min}$ at room temperature and fixed in 1\% paraformaldehyde (Becton Dickinson). Stained cells were incubated with 1\% FACS permeabilizing solution (Becton Dickinson), followed by phycoerythrin (PE)-conjugated anti-human IL-10 or IL-4 (eBioscience, clones JES3-9D7, IgG1א and 8D4-8, IgG1א respectively) or isotype-matched controls and 5000 gated events were analysed on a FACSCalibur ${ }^{\text {Tm }}$ instrument with CellQuest software (Becton Dickinson). Instrument set up and colour compensation was done using BD Calibrite ${ }^{\mathrm{TM}}$ beads and FACSComp software. Apoptosis was monitored by measuring the proportion of Annexin V-positive, PI-negative cells using PI/Annexin V kits (BD PharMingen) [25].

\section{Assessment of endotoxin tolerance}

Endotoxin tolerance was monitored by measuring production of TNF- $\alpha$ and IL-10 by monocytes in response to LPS after preincubation with LPS or mAb 1F7 [26]. Isolated monocytes at $5 \times 10^{5}$ cells $/ \mathrm{ml}$ were cultured for $18 \mathrm{~h}$ with $100 \mathrm{ng} / \mathrm{ml} \mathrm{LPS,} 1.92 \mu \mathrm{g} / \mathrm{ml} \mathrm{mAb} 1 \mathrm{~F} 7$ or in plain medium. After $18 \mathrm{~h}$ of culture, the monocytes were washed three times with endotoxin-free PBS, and cultured for an additional $4 \mathrm{~h}$ with $1 \mu \mathrm{g} / \mathrm{ml}$ LPS. Incubation of monocytes with $100 \mathrm{ng} / \mathrm{ml}$ LPS, followed by rechallenge with $1 \mu \mathrm{g} / \mathrm{ml}$ LPS is a standard method for assessing endotoxin tolerance $[25,26]$. At the end of the culture period, cell-free supernatants were collected and endotoxin tolerance assessed by measuring human TNF- $\alpha$ and IL-10 with Ready-SET-Go test kits (eBioscience) according the manufacturer's instructions.

\section{Statistical analysis}

Data from independent experiments were used to calculate mean values $\pm \mathrm{SE}$ and differences were tested for statistical significance $(\mathrm{p} \leq 0.05)$ by Student's paired $t$ test. ANOVA for repeated measures was used for analysis of mAb 1F7 action on endotoxin tolerance induction and cytokine production.

\section{Results}

The 1F7 mAb induces IL-10 production by PBMC in vitro in a dose- and time-dependent manner

We first tested whether 1F7 mAb stimulated IL-10 production by normal human PBMC in vitro. Freshly isolated
PBMC from 10 healthy donors were incubated individually for $18 \mathrm{~h}$ with $0.48,0.96,1.44$ and $1.92 \mu \mathrm{g} / \mathrm{ml} 1 \mathrm{~F} 7$ $\mathrm{mAb}$, after which IL-10 was measured in culture supernatants. The starting concentration of IgM mAb in the hybridoma supernatant was $1.92 \mu \mathrm{g} / \mathrm{ml}$, therefore, dose response was titrated from this level. We found that $1 \mathrm{~F} 7$ $\mathrm{mAb}$ at $0.96,1.44$ and $1.92 \mu \mathrm{g} / \mathrm{ml}$ induced significant $(\mathrm{p}=0.01)$ IL-10 production in PBMC with responses increasing in a dose-dependent manner (Figure 1a). The timing of $1 \mathrm{~F} 7 \mathrm{mAb}$ stimulation of IL-10 production was studied at $1.92 \mu \mathrm{g} / \mathrm{ml} 1 \mathrm{~F} 7 \mathrm{mAb}$ because this concentration induced the most IL-10 secretion. 1F7 mAb-treated cells were incubated for 24,48 and $72 \mathrm{~h}$, after which the IL-10 concentration in culture supernatants was measured. These time course studies (Figure 1b) showed maximal IL-10 concentration at $24 \mathrm{~h}$ (62.7 \pm $37.4 \mathrm{pg} / \mathrm{ml})$, with a gradual decrease at $48 \mathrm{~h}(43.1 \pm$ $17.9 \mathrm{pg} / \mathrm{ml})$ and $72 \mathrm{~h}(27.1 \pm 7.5 \mathrm{pg} / \mathrm{ml})(\mathrm{p}=0.03)$. To test

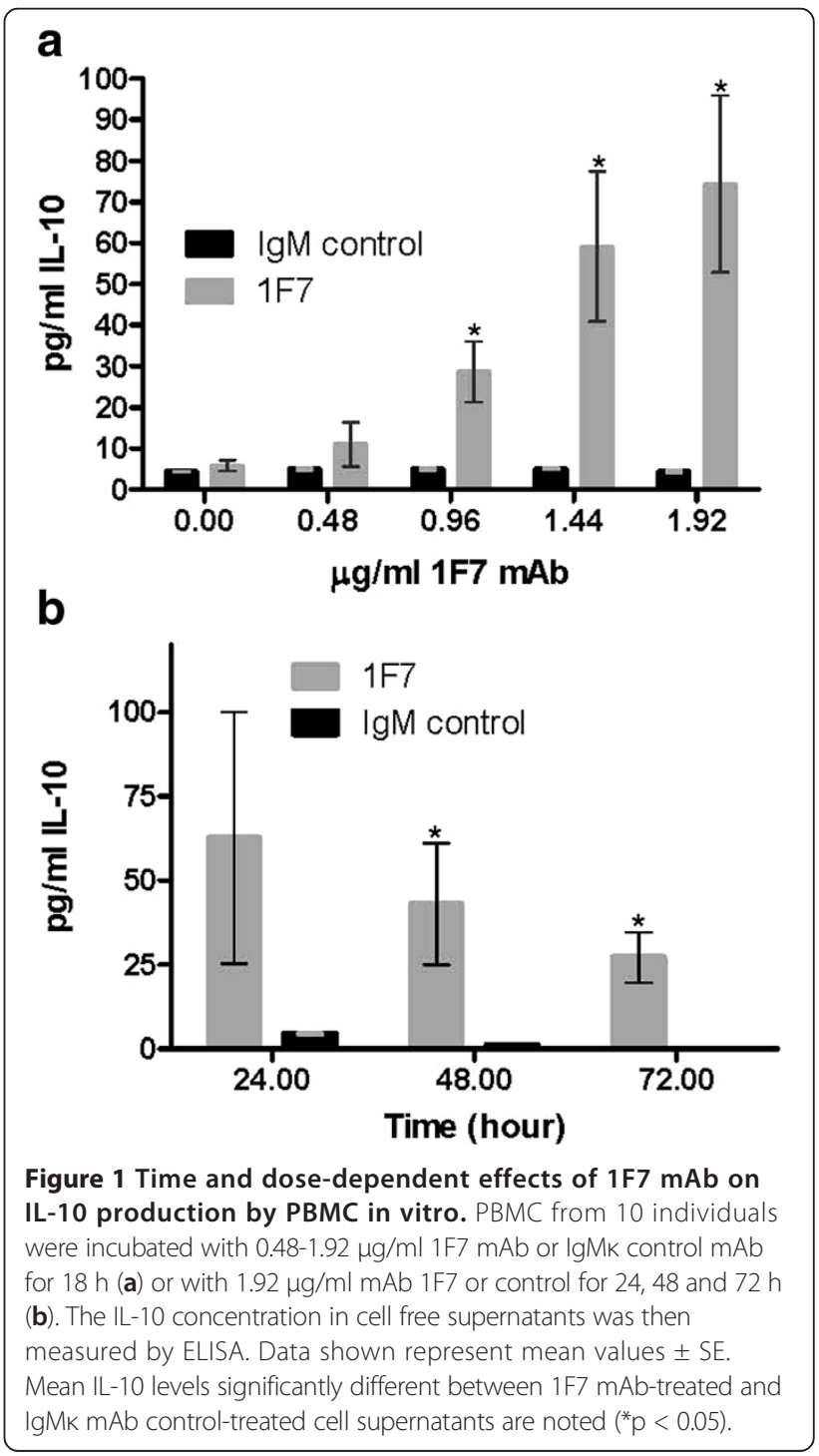


whether the decreasing IL-10 production over time reflected effects of $1 \mathrm{~F} 7 \mathrm{mAb}$ on cell survival, we assessed apoptotic and necrotic cell death by flow cytomtery. The results indicate that $1 \mathrm{~F} 7 \mathrm{mAb}$ does not cause apoptotic (Figure 2a) or necrotic (Figure 2b) cell death. Thus, secretion of IL-10 by PBMC dramatically increases shortly after treatment with 1F7 mAb, but then decreases as incubation extends past $24 \mathrm{~h}$.

\section{F7 mAb induces IL-10 production by $\mathrm{CD} 14^{+}$monocytes and $\mathrm{CD}^{+} 6^{+}$lymphocytes}

Next, we studied which PBMC subsets produce IL-10 in response to $1 \mathrm{~F} 7 \mathrm{mAb}$. Freshly isolated PBMC from the same 10 healthy donors were incubated with $0.48,0.96$, 1.44 and $1.92 \mu \mathrm{g} / \mathrm{ml} 1 \mathrm{~F} 7 \mathrm{mAb}$ for $18 \mathrm{~h}$ and then surface stained for CD14 and CD36, permeabilized, stained for intracellular IL-10 and analyzed by flow cytometry (Figure 3a). We found that in a dose-dependent manner, 1F7 mAb significantly increased the percentage of $\mathrm{CD}^{+} 6^{+}$ lymphocytes $(\mathrm{p}=0.02)$ and $\mathrm{CD} 14^{+}$monocytes $(\mathrm{p}=0.03)$ producing IL-10 (Figure $3 \mathrm{~b}, \mathrm{c}$ ). To determine the major source of IL-10 production in response to $1 \mathrm{~F} 7 \mathrm{mAb}$, we

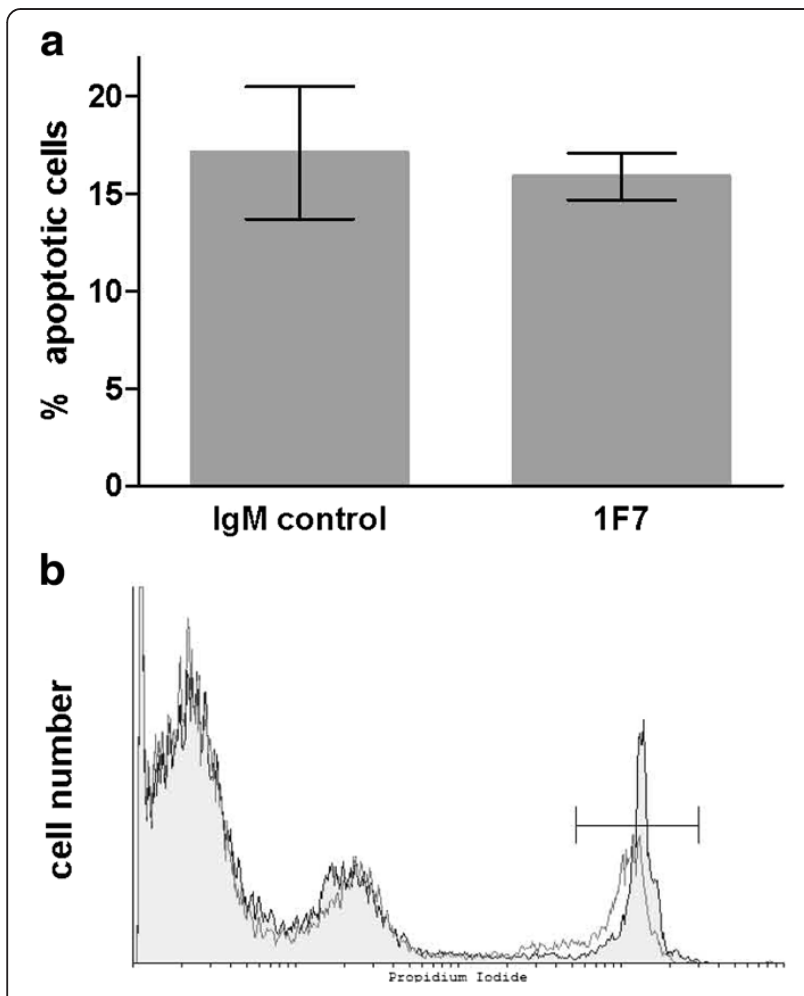

Figure 2 Effect of $1 F 7$ mAb on PBMC apoptosis and necrosis. PBMC were incubated with $1.92 \mathrm{\mu g} / \mathrm{ml} 1 \mathrm{~F} 7 \mathrm{mAb}$ or IgMk mAb control for $72 \mathrm{~h}$ and analyzed by flow cytometry for Annexin $\mathrm{V}^{+}$, propidium iodide (PI)- apoptotic cells (a) or $\mathrm{Pl}^{+}$necrotic cells (b). Data shown in (a) represent mean values $\pm S E, n=10$. The shaded area of a representative flow cytometry plot (b) corresponds to $\operatorname{lgMk}$ control mAb-treated cells $\left(13.9 \% \mathrm{PI}^{+}\right)$and the non-shaded area corresponds to $1 \mathrm{~F} 7 \mathrm{mAb}$-treated cells $\left(12.0 \% \mathrm{Pl}^{+}\right)$. next compared production of IL-10 by $\mathrm{CD} 14^{+}$monocytedepleted and intact PBMC from 5 of the 10 healthy donors. $\mathrm{CD} 14^{+}$cells were depleted using magnetic beads and the remaining cells incubated with $1.92 \mu \mathrm{g} / \mathrm{ml} 1 \mathrm{~F} 7 \mathrm{mAb}$ or IgM control for $24 \mathrm{~h}$, after which the IL-10 concentration in culture supernatants was measured. As shown in Figure 3d, intact PBMC from the 5 selected healthy donors incubated with $1 \mathrm{~F} 7 \mathrm{mAb}$ produced similar amounts of IL-10 $(75.6 \pm 30.4 \mathrm{pg} / \mathrm{ml})$ to the amounts previously produced by the $1 \mathrm{~F} 7 \mathrm{mAb}$ stimulated $\mathrm{PBMC}$ of all 10 healthy donors $(62.7 \pm 37.4 \mathrm{pg} / \mathrm{ml}$, Figure 1$)$. Depletion of $\mathrm{CD}_{14}{ }^{+}$monocytes dramatically decreased IL-10 production (Figure 3d). However, the $1 \mathrm{~F} 7 \mathrm{mAb}$ still induced significantly more IL-10 production by $\mathrm{CD} 14^{+}$ monocyte-depleted PBMC than was induced by the IgMK $\mathrm{mAb}$ control $(12.2 \pm 4.8 \mathrm{pg} / \mathrm{ml}$ versus $1.99 \pm$ $0.98 \mathrm{pg} / \mathrm{ml}, \mathrm{p}=0.02$, Figure $3 \mathrm{~d}$ ).

\section{Time-dependent 1F7 mAb stimulation of cytokine production by PBMC subsets}

Next, we studied the time-dependent action of 1F7 mAb on IL-4 and IL-10 production by normal human monocytes and lymphocytes. Freshly isolated PBMC were incubated with $1.92 \mu \mathrm{g} / \mathrm{ml} 1 \mathrm{~F} 7 \mathrm{mAb}$ or IgMk control mAb for 24,48 and $72 \mathrm{~h}$ and the percentage of monocytes and $\mathrm{CD}^{2} 6^{+}$lymphocytes producing IL-4 or IL-10 analyzed by flow cytometry. Similar to the time course studies carried out with PBMC (Figure 1b), 1F7 mAb significantly increased the percentage of IL-10 producing monocytes at $24 \mathrm{~h}(\mathrm{p}=0.001)$, with a gradual decrease at $48 \mathrm{~h}$ and $72 \mathrm{~h}$ (Figure $4 \mathrm{a}$ ). In contrast, $1 \mathrm{~F} 7 \mathrm{mAb}$ significantly increased the percentage of IL-10 producing CD36 ${ }^{+}$ lymphocytes at both $24 \mathrm{~h}(\mathrm{p}=0.005)$ and $72 \mathrm{~h}(\mathrm{p}=0.002)$. The temporal pattern of $1 \mathrm{~F} 7 \mathrm{mAb}$ action on IL-4 production by $\mathrm{CD} 14^{+}$monocytes was similar to its action on IL-10 production with a peak at 24 hours and gradual decrease at 48 and 72 hours (Figure 4b). In contrast to 1F7 mAb's action on IL-10 production by both monocytes and lymphocytes, we saw no statistically significant differences in IL-4 production between $1 \mathrm{~F} 7 \mathrm{mAb}$ and IgMk control mAb treated cells over the 24-72 $\mathrm{h}$ incubation period (Figure 4a, b). Thus, we conclude that 1F7 $\mathrm{mAb}$ selectively induces short-term production of IL-10 by monocytes, which begins to decline after 24 hours.

\section{F7 mAb enhances TLR and NOD agonist-induced IL-10 production by monocytes}

Recognition of pathogen-associated molecular patterns by TLRs and NOD proteins is an important initial step in mounting an immune response against bacteria and some viruses. Therefore, we investigated how $1 \mathrm{~F} 7 \mathrm{mAb}$ influenced production of IL-10 by isolated monocytes treated with TLR and NOD agonists. TLR agonist LPS and NOD agonist PGN were added to isolated monocytes together with 1F7 


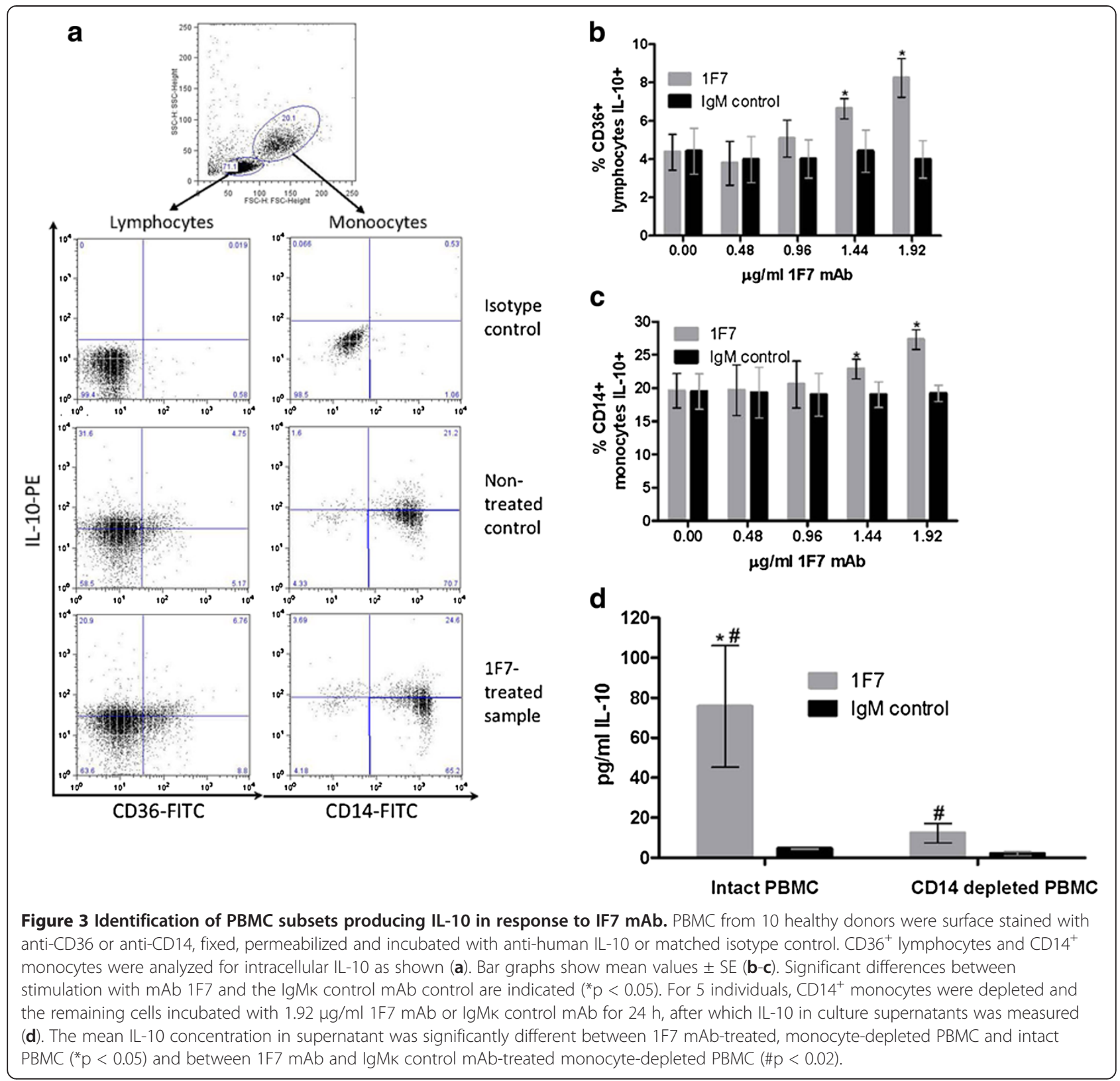

$\mathrm{mAb}$ or IgMk control $\mathrm{mAb}$ at $1.92 \mu \mathrm{g} / \mathrm{ml}$ for $72 \mathrm{~h}$ and IL-10 production was measured in culture supernatants (Figure 5). We found that 1F7 mAb significantly increased IL-10 production by untreated (NT) monocytes and augmented IL-10 production by LPS- and PGN-stimulated monocytes $(\mathrm{p}<0.05)$. These results were somewhat unexpected as it was shown above that 1F7 mAb dramatically increases production of IL-10 by monocytes at $24 \mathrm{~h}$, but then the concentration of IL-10 decreases at 48 and $72 \mathrm{~h}$.

\section{F7 mAb induces monocyte endotoxin tolerance}

To determine whether 1F7 mAb-induced production of IL-10 is associated with anti-inflammatory (alternative) activation of monocytes, we next studied LPS tolerance induction in vitro. Monocytes were pretreated with LPS at $100 \mathrm{ng} / \mathrm{ml}$ or $1 \mathrm{~F} 7 \mathrm{mAb}$ at $1.92 \mu \mathrm{g} / \mathrm{ml}$ for $18 \mathrm{~h}$, after which the cells were washed with LPS-free PBS and restimulated with LPS or 1F7 for another $4 \mathrm{~h}$. Production of TNF- $\alpha$ and IL-10 was subsequently measured in cell culture supernatants. We found that at $18 \mathrm{~h}$ incubation, LPS, but not 1F7 mAb, stimulated monocyte TNF- $\alpha$ production (Figure $6 \mathrm{a}$ ). This is consistent with 1F7 mAb causing early anti-inflammatory (alternative) activation of unstimulated monocytes. As expected, the monocytes developed homologous tolerance to LPS challenge shown by declining production of TNF- $\alpha$ after overnight LPS treatment (Figure 6a, NT+LPS versus LPS+LPS treatment groups). Similar to the LPS-treated 

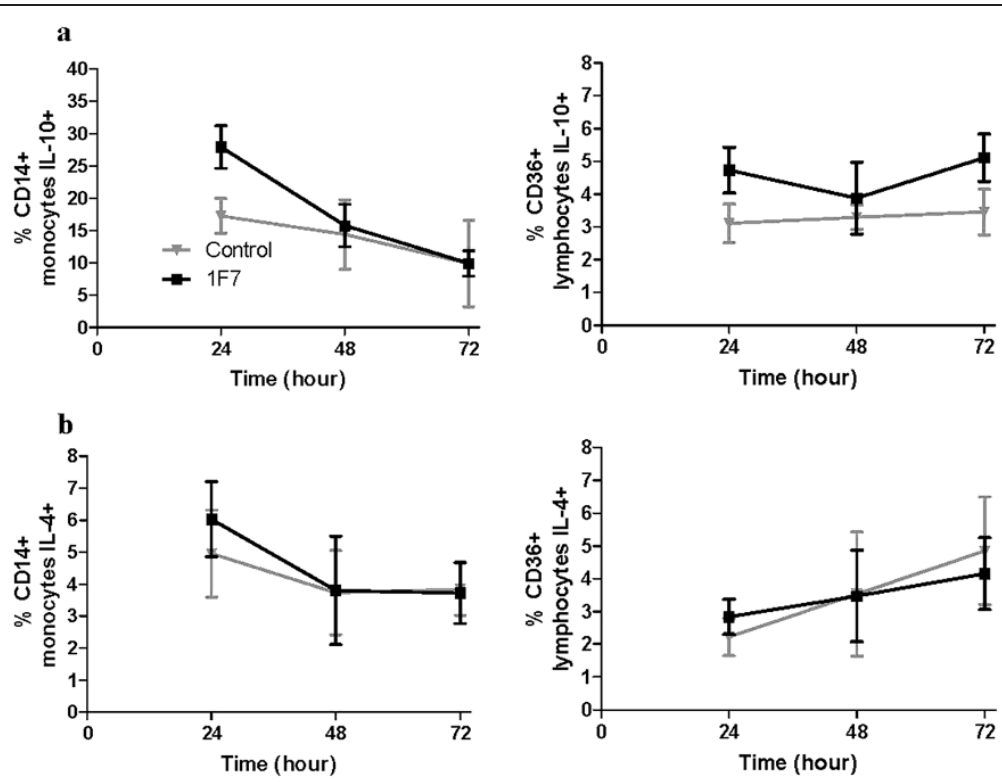

Figure 4 Time-dependent effects of $1 \mathrm{~F} 7 \mathrm{mAb}$ on IL-4 and IL-10 production by CD14 ${ }^{+}$monocytes and CD $36^{+}$lymphocytes. PBMC from 10 healthy donors were incubated with $1.92 \mathrm{\mu g} / \mathrm{ml} 1 \mathrm{~F} 7 \mathrm{mAb}$ or IgMk mAb control for 24,48 and $72 \mathrm{~h}$ and surface stained with anti-CD36 or antiCD14. Cells were then fixed, permeabilized, incubated with anti-human IL-10, anti-IL-4 or isotype-matched controls and analyzed by flow cytometry for intracellular IL-10 (a) and IL-4 (b). Gating for intracellular cytokine analysis was done as shown in Figure 3. Data shown represent mean values $\pm \mathrm{SE}$.

monocytes, monocytes treated overnight with $1 \mathrm{~F} 7 \mathrm{mAb}$ also developed tolerance to subsequent LPS challenge as shown by a statistically significant decline in production of TNF- $\alpha$ (Figure $6 \mathrm{a}, \mathrm{NT}+\mathrm{LPS}$ versus $1 \mathrm{~F} 7 \mathrm{mAb}+\mathrm{LPS}$ treatment groups, $\mathrm{p}<0.002$ ).

Next, we studied how monocytes responded in terms of IL-10 production to overnight LPS treatment (Figure 6b). We found that $18 \mathrm{~h}$ incubation with $1 \mathrm{~F} 7 \mathrm{mAb}$, but not

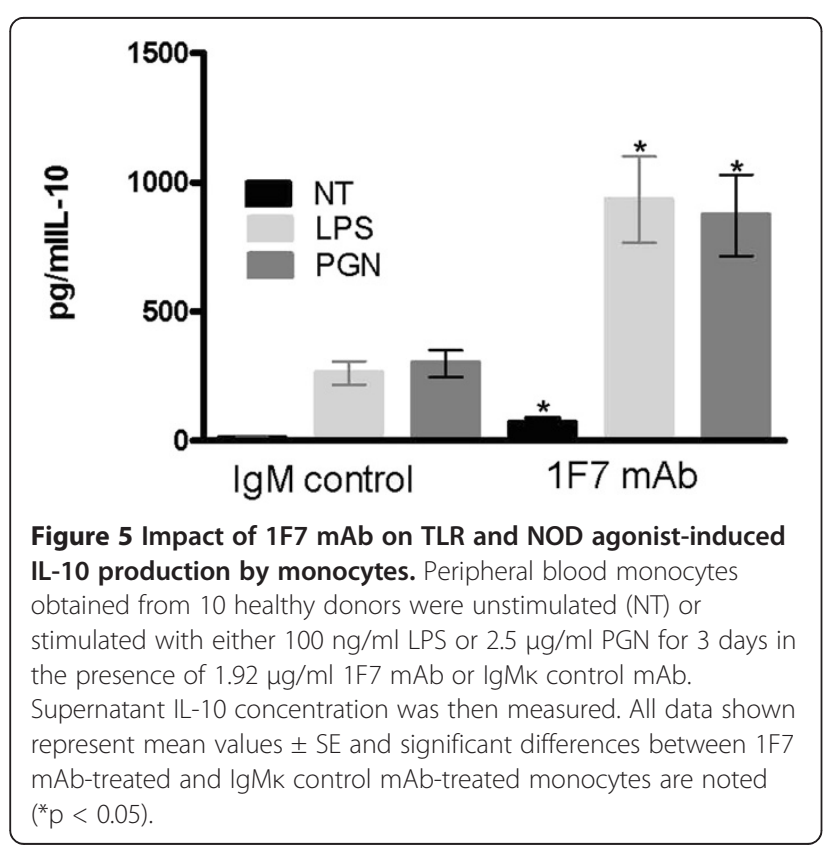

LPS induced monocyte IL-10 production (Figure 6b), consistent with $1 \mathrm{~F} 7 \mathrm{mAb}$ inducing early anti-inflammatory (alternative) activation of monocytes. LPS-pretreated monocytes produced a low, but detectable level of IL-10 following repeated LPS stimulation (Figure $6 \mathrm{~b}, \mathrm{p}<0.04$ ). Overnight culture of monocytes with either no treatment or with 1F7 $\mathrm{mAb}$ treatment prior to LPS restimulation resulted in a significantly higher level of IL-10 compared to repeated LPS treatments (Figure 6b, $\mathrm{p}<0.04$ ).

\section{Discussion}

Cytokine production profile is closely associated with the outcome of viral infection. A predominance of proinflammatory TH1-type cytokines such as IL-12 and IFN- $\gamma$ portends viral clearance or control, whereas dominance of anti-inflammatory cytokines like IL-4 or IL-10 is more likely to herald chronic infection [12-15]. This suggests that pathogens establishing chronic infection have evolved mechanisms to skew host responses towards cytokine profiles that favour their persistence. In a number of infections, the level and timing of IL-10 production is a pivotal factor in determining pathogen clearance versus pathogen persistence [27-30]. We previously demonstrated an association between development of chronic HCV infection, the level of anti-HCV antibodies expressing a common idiotype recognized by the 1F7 mAb and expansion of B1 B cells expressing the same idiotype [9]. Therefore, we speculated that HCV may exploit a link between B1 B cell activation, induction of 1F7 


\section{a}

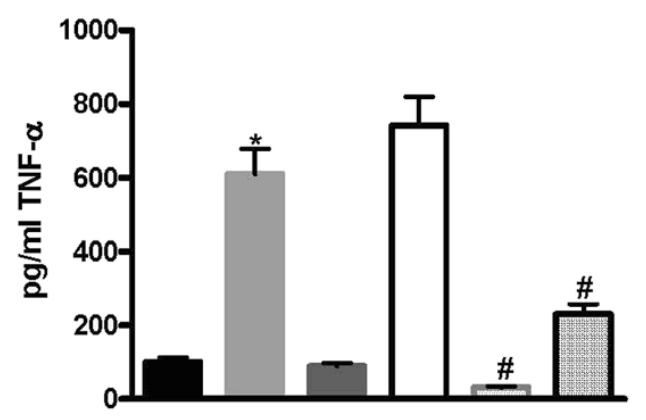

$\begin{array}{lllllll}\text { Pretreatment } 18 \mathrm{~h} & \text { NT } & \text { LPS } & 1 \mathrm{~F} 7 & \text { NT } & \text { LPS } & 1 \mathrm{~F} 7\end{array}$ Restimulation $4 \mathrm{~h} \quad \mathrm{NT}$ NT NT LPS LPS LPS

\section{b}

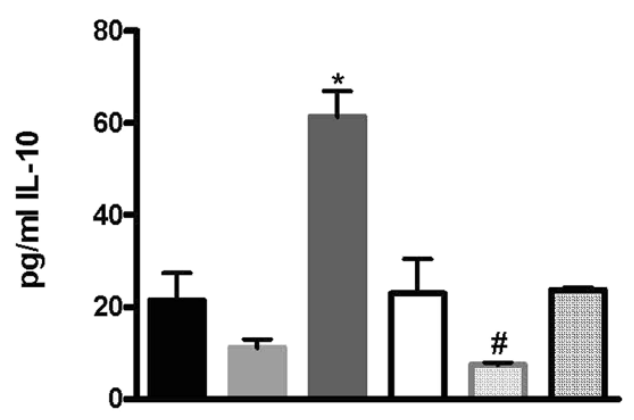

$\begin{array}{lllllll}\text { Pretreatment } 18 \mathrm{~h} & \text { NT } & \text { LPS } & 1 \mathrm{~F} 7 & \text { NT } & \text { LPS } & 1 \mathrm{~F} 7\end{array}$ Restimulation $4 \mathrm{~h} \quad \mathrm{NT}$ NT NT LPS LPS LPS

Figure 6 Influence of 1F7 mAb treatment on monocyte endotoxin tolerance. Monocytes from 10 healthy donors were pretreated with $100 \mathrm{ng} / \mathrm{ml}$ LPS or $1.92 \mu \mathrm{g} / \mathrm{ml} 1 \mathrm{~F} 7 \mathrm{mAb}$ for $18 \mathrm{~h}$, washed with LPS-free PBS and incubated for an additional $4 \mathrm{~h}$ with $1 \mu \mathrm{g} / \mathrm{ml}$ LPS or $1.92 \mu \mathrm{g} / \mathrm{ml} 1 \mathrm{~F} 7 \mathrm{mAb}$. Levels of TNF-a (a) and IL-10 (b) in supernatants were then measured. All data shown represent mean values \pm SE. Significant differences by repeated ANOVA measures are noted between NT, LPS or 1F7 treatment $\left({ }^{*} p<0.05\right)$ and between LPS re-stimulated pairs $(\# p<0.05)$

Id-expressing antibodies and IL-10 production to evade the immune system and establish chronic infection.

In this study, we found that the $1 \mathrm{~F} 7 \mathrm{mAb}$ itself specifically triggered IL-10 production by freshly-isolated PBMC in a time and dose-dependent manner. Both $\mathrm{CD}^{+} 6^{+}$lymphocytes and $\mathrm{CD} 14^{+}$monocytes produced IL-10 in response to $1 F 7 \mathrm{mAb}$. Although the percentage of $\mathrm{CD}_{36}{ }^{+}$lymphocytes producing IL-10 doubled following 1F7 mAb treatment, in absolute terms this was a small number of responding cells compared to the number of monocytes producing IL-10 in response to 1F7 mAb treatment. Monocytes generally represent $\sim 20 \%$ of total PBMC, while CD $36^{+}$lymphocytes represent $<1 \%$ of the lymphocyte population. Depletion of $\mathrm{CD}_{1} 4^{+}$ monocytes reduced $1 \mathrm{~F} 7 \mathrm{mAb}$-stimulated IL-10 production by $>80 \%$, therefore, we concluded that $\mathrm{CD}^{+} 6^{+}$ lymphocytes are a minor source of IL-10 production following 1F7 mAb stimulation. The initial induction of monocyte IL-10 production by $1 \mathrm{~F} 7 \mathrm{mAb}$ was followed by imposition of classical endotoxin tolerance in that the pro-inflammatory response to TLR ligands such as LPS was substantially blunted. If these in vitro responses to the 1F7 mAb itself reflect responses that occur in vivo following activation of B1 B cells bearing Ig with the 1F7 idiotype, this could represent a two-pronged approach for pathogens to suppress immune responses that favour clearance. Since the idiotype recognized by mAb $1 F 7$ is more common on $\mathrm{CD}^{+} \mathrm{B} 1 \mathrm{~B}$ cells and these cells produce IL-10 [9-11], we initially felt that 1F7 interacting in vitro with the Ig B cell receptor of B1 B cells might mimic in vivo interactions with $\mathrm{HCV}$ proteins that directly trigger IL-10 production. However, the major source of IL-10 following exposure to $1 \mathrm{~F} 7 \mathrm{mAb}$ is monocytes, not B cells, indicating that the IL-10 is not produced as a direct effect of $1 \mathrm{~F} 7 \mathrm{mAb}$ binding to the Ig $\mathrm{B}$ cell receptor of $\mathrm{B} 1 \mathrm{~B}$ cells. While the mechanism by which the $1 \mathrm{~F} 7 \mathrm{mAb}$ itself stimulates monocyte production of IL-10 in vitro is non-antigen specific, it may represent a mechanism by which $\mathrm{HCV}$ and other chronic viral and bacterial pathogens selectively exploit idiotypic connections to suppress immune responses. It was recently shown that by differentially affecting TLR4 and TLR8 pathways, IL-10 may selectively modulate monocyte functions in persons with chronic $\mathrm{HCV}$ infection [31]. This corroborates our data suggesting that IL-10 -mediated inhibition of the TLR4 signaling pathway in monocytes induces endotoxin tolerance and favours alternative activation of monocytes [31].

Convergent selection of anti-HCV antibodies bearing the 1F7 idiotype occurs during $\mathrm{HCV}$ infection and involves activation of B1 B cells [9]. Due to the high degree of $\mathrm{V}$ region connectivity between $\mathrm{B} 1 \mathrm{~B}$ cells, they may be activated either by direct interaction with $\mathrm{HCV}$ proteins or through interaction with other antibodies simulated by HCV [32,33]. Since the $1 F 7 \mathrm{mAb}$ is a multimeric IgM mAb, its overall high avidity may produce exaggerated effects in vitro compared to IgG antibodies. However, the high $\mathrm{V}$ region connectivity and high frequency of expression of the 1F7 idiotype on B1 $B$ cells suggests that immune complexes containing 1F7 Id-expressing and 1F7-like antibodies will form when B1 $B$ cells are activated. If so, these complexes will have similar overall avidity to the 1F7 IgM mAb. These complexes or the 1F7-like antibodies themselves [8], should act on circulating monocytes during acute $\mathrm{HCV}$ infection in the same way as the $1 \mathrm{~F} 7 \mathrm{mAb}$ acts in vitro, by inducing IL-10 production and endotoxin tolerance. Suppression of proinflammatory cytokines such as IFN- $\gamma$, and IL- 12 by monocyte-derived IL-10 induced in this manner would also favour chronic $\mathrm{HCV}$ infection. 
Thus, early activation of B1 B cells producing Ig expressing the 1F7 idiotype and B1 B cells with complementary 1F7 Id-like Ig receptors could underlie the association we observed between high levels of antibodies expressing the 1F7 idiotype and chronic HCV infection [9]. Stimulation of 1F7 Id-expressing antibodies by chronic pathogens susceptible to phagocytosis and intracellular killing could favour their persistence through both the direct IL-10 production and subsequent endotoxin tolerance imposed on monocytes.

The idea that pathogens can exploit idiotypic interactions inherent to the humoral immune system was initially proposed by Irun Cohen [34-36]. Common idiotypes arise in the setting of chronic infection or chronic immune activation and are often carried on antibodies termed natural antibodies [37]. Natural antibodies are produced by B1 B cells and demonstrate cross-reactivity, autoreactivity and high $\mathrm{V}$ region connectivity [38-40]. Activating immune responses along this axis of complementary autoreactive and cross-reactive idiotypic dominance would in itself benefit pathogens in that the response would be more likely to remain diffuse. If activating immune responses along this axis also leads to IL-10 production and monocyte endotoxin tolerance, prospects for establishing chronic infection would be further enhanced. In this regard, all of the pathogens so far shown to stimulate antibodies expressing the 1F7 idiotype either predominantly (HCV) or uniformly (HIV and SIV) establish chronic infection. This suggests that chronic pathogens have evolved to exploit inherent immune system structural characteristics such as high connectivity and functional coupling to IL-10 induction, which are better suited to preserve selftolerance than to provide protection against pathogens.

\section{Conclusions}

Our previous study showed an association between 1F7 Id expression levels and chronic HCV infection [8]. In the present study, we investigated the potential role of antibodies bearing the 1F7 Id in modulating monocyte cytokine responses. We observed that the mAb 1F7 itself induced IL-10 production by unstimulated and TLR- or NLR-agonist-stimulated monocytes and subsequently imposed endotoxin tolerance on those monocytes. However, pretreatment of monocytes with LPS followed by LPS was significantly different from pretreatment with $1 F 7 \mathrm{mAb}$ followed by LPS in terms of both TNF- $\alpha$ production and IL-10 production. This indicates that monocyte endotoxin tolerance imposed by $1 \mathrm{~F} 7 \mathrm{mAb}$ treatment is incomplete compared to LPS-induced monocyte endotoxin tolerance. The 1F7 mAb probably provides a weaker primary stimulus than LPS and acts through a different signaling pathway. A distinct or divergent signaling pathway from LPS is also suggested by the lack of significant TNF- $\alpha$ production in response to $1 \mathrm{~F} 7 \mathrm{mAb}$. Although the receptor on monocytes that mediates $1 \mathrm{~F} 7 \mathrm{mAb}$ signaling is unknown, the effects are selective and specific. Further elucidation of the immunological and biochemical basis for the association between 1F7 Id expression levels and chronic HCV infection and for the selective action of 1F7 $\mathrm{mAb}$ on monocytes may aid in the design of novel therapeutic and prophylactic strategies against $\mathrm{HCV}$ and other chronic pathogens.

\section{Competing interests}

Michael Grant is a member of the Scientific Advisory Board of Network Immunology Inc., a private company developing vaccines based on the 1F7 $\mathrm{mAb}$.

\section{Authors' contributions}

MDG and TKD carried out the study design, project oversight, data analysis and manuscript preparation. DAP and AGS carried out sample collection, flow cytometry, data analysis and manuscript preparation. DAP also contributed to study design, and oversaw the lipopolysaccharide tolerance experiments. All authors read and approved the final manuscript.

\section{Acknowledgements}

M.G. and T.D. acknowledge support from the Canadian Institutes of Health Research through an international development grant to initiate their collaboration.

\section{Author details}

1Laboratory of Immunology and Virology, "Armenicum" Research Center CJSC, Yerevan, Armenia. ${ }^{2}$ Institute of Molecular Biology NAS RA, Yerevan, Armenia. ${ }^{3}$ Institute of Epidemiology MH RA, Yerevan, Armenia. ${ }^{4}$ Division of BioMedical Sciences, Faculty of Medicine, Memorial University of Newfoundland, St. John's, NL, Canada.

Received: 2 November 2012 Accepted: 3 April 2013

Published: 5 April 2013

\section{References}

1. Bona CA, Goldberg B, Rubinstein L: Regulatory idiotopes, parallel sets and internal image of the antigen within the polyfructosan-A48 idiotypic network. Ann Immunol (Paris) 1984, 135C:107-115.

2. Sela O, El-Roeiy A, Isenberg DA, Kennedy RC, Colaco CB, Pinkhas J: A common anti-DNA idiotype in sera of patients with active pulmonary tuberculosis. Arthritis Rheum 1987, 30:50-55.

3. Muller S, Wang H, Silverman GJ, Bramlet G, Haigwood N, Kohler H: B-cell abnormalities in AIDS: stable and clonally-restricted antibody response in HIV-1 infection. Scand J Immunol 1993, 38:327-334.

4. Wang H-T, Muller S, Zolla-Pazner S, Kohler H: Human monoclonal and polyclonal anti-human immunodeficiency virus-1 antibodies share a common clonotypic specificity. Eur J Immunol 1992, 22:1749-1755.

5. Grant M, Whaley M, Mayne A, Hoffmann G, Ansari AA: Similar abnormalities of idiotype and immunoglobulin light chain expression and of cellmediated cytotoxicity in HIV-infected humans and simian immunodeficiency virus (SIV)-infected rhesus macaques. Immunol Cell Biol 1996, 174:38-44

6. Grant M: Antibody convergence along a common idiotypic axis in immunodeficiency virus and hepatitis C virus infections. J Med Virol 2002, 66:13-21.

7. Muller S, Wang H-T, Kaveri S, Chattopadhyay S, Kohler H: Generation and specificity of monoclonal anti-idiotypic antibodies against human HIVspecific antibodies. J Immunol 1991, 147:933-941.

8. Wang QL, Wang H-T, Blalock E, Muller S, Kohler H: Identification of an idiotypic peptide recognized by autoantibodies in human immunodeficiency virus-1 -infected individuals. J Clin Invest 1995, 96:775-780.

9. Davtyan TK, Hovsepyan MP, Mkhitaryan LM, Hakobyan GS, Brazil A, Barrett L, Hirsch G, Peltekian KM, Grant MD: The 1F7 idiotype is selectively expressed on $\mathrm{CD} 5+\mathrm{B}$ cells and elevated in chronic hepatitis $C$ virus infection. Immunol Cell Biol 2009, 87:457-463.

10. Hedrich $\mathrm{CM}$, Bream JH: Cell type-specific regulation of IL-10 expression in inflammation and disease. Immunol Res 2010, 47:185-206. 
11. Moore KW, de Waal MR, Coffman RL, O'Garra A: Interleukin-10 and the interleukin-10 receptor. Annu Rev Immunol 2001, 19:683-765.

12. Byrnes AA, Li DY, Park K, Thompson D, Mocilnikar C, Mohan P, Molleston JP, Narkewicz M, Zhou H, Wolf SF, Schwarz KB, Karp CL: Modulation of the IL12/IFN-gamma axis by IFN-alpha therapy for hepatitis C. J Leukoc Biol 2007, 81:825-834

13. Tsai SL, Liaw YF, Chen MH, Huang CY, Kuo GC: Detection of type 2-like Thelper cells in hepatitis $C$ virus infection: implications for hepatitis C virus chronicity. Hepatology 1997, 25:449-458.

14. Kakumu S, Okumura A, Ishikawa T, Iwata K, Yano M, Yoshioka K: Production of interleukins 10 and 12 by peripheral blood mononuclear cells (PBMC) in chronic hepatitis C virus (HCV) infection. Clin Exp Immunol 1997, 108:138-143.

15. Osna N, Silonova G, Vilgert N, Hagina E, Kuse V, Giedraitis V, Zvirbliene A, Mauricas M, Sochnev A: Chronic hepatitis C: T-helper1/T-helper2 imbalance could cause virus persistence in peripheral blood. Scand J Clin Lab Invest 1997, 57:703-710.

16. Kamal SM, Fehr J, Roesler B, Peters T, Rasenack JW: Peginterferon alone or with ribavirin enhances HCV-specific CD4 T helper 1 responses in patients with chronic hepatitis C. Gastroenterology 2002, 123:1070-1083.

17. Kamal SM, Ismail A, Graham CS, He Q, Rasenack JW, Peters T, Tawil AA, Fehr JJ, Khalifa Kel S, Madwar MM, Koziel MJ: Pegylated interferon alfa therapy in acute hepatitis C: relation to hepatitis $C$ virus-specific $T$ cell response kinetics. Hepatology 2004, 39:1721-1731.

18. Thimme R, Bukh J, Spangenberg HC, Wieland S, Pemberton J, Steiger C, Govindarajan S, Purcell RH, Chisari FV: Viral and immunological determinants of hepatitis $C$ virus clearance, persistence, and disease. Proc Natl Acad Sci USA 2002, 99:15661-15668.

19. Brooks DG, Trifilo MJ, Edelmann KH, Teyton L, McGavern DB, Oldstone MB: Interleukin-10 determines viral clearance or persistence in vivo. Nat Med 2006, 12:1301-1309.

20. Aborsangaya KB, Dembinski I, Khatkar S, Alphonse MP, Nickerson P, Rempe JD: Impact of aboriginal ethnicity on HCV core-induced IL-10 synthesis: interaction with IL-10 gene polymorphisms. Hepatology 2007, 45:623-630.

21. Barrett LB, Gallant M, Howley C, Bowmer MI, Hirsch G, Peltekian K, Grant M: Enhanced IL-10 production in response to hepatitis $C$ virus proteins by peripheral blood mononuclear cells from human immunodeficiency virus-infected individuals. BMC Immunol 2008, 9:28-44.

22. Dogra G, Chakravarti A, Kar P, Chawla YK: Polymorphism of tumor necrosis factor-alfa and interleukin-10 gene promoter region in chronic hepatitis $C$ virus patients and their effect on pegylated interferon-alfa therapy response. Hum Immunol 2011, 72:935-939.

23. Barrett L, Dai C, Gamberg J, Gallant M, Grant M: Circulating CD14-CD36+ peripheral blood mononuclear cells constitutively produce interleukin-10. J Leukoc Biol 2007, 82:152-160.

24. Procheray F, Viaud S, RimaniolL AC, Leone C, Samah B, Dereuddre-Bosquet $\mathrm{N}$, Dormont D, Gras G: Macrophage activation switching: an asset for the resolution of inflammation. Clin Exp Immunol 2005, 142:481-489.

25. Davtyan TK, Hakobyan GS, Avetisyan SA, Harutyunyan VA: Engaging antiinflammatory mechanisms and triggering inflammatory effectors apoptosis during Familial Mediterranean fever attack. Inflam Res 2008, 57:65-74.

26. Davtyan TK, Hakobyan GS, Avetisyan SA, Mkrtchyan NR: Impaired endotoxin tolerance induction in patients with familial Mediterranean fever. Pathobiology 2006, 73:26-39.

27. Nelson DR, Lau JY: Pathogenesis of hepatocellular damage in chronic hepatitis C virus infection. Clin Liver Dis 1997, 1:515-528.

28. Eksioglu EA, Bess J, Jones G, Dettloff J, Dangmeon P, Dong H-J, Zhu H, Firpi $R, X u Y$, Nelson DR, Liu C: Characterization of anti-HCV antibodies in IL-10 -treated patients. Viral Immunol 2010, 23:359-368.

29. Yoneda S, Umemura T, Katsuyama Y, Kamijo A, Joshita S, Komatsu M, Ichijo T, Matsumoto A, Yoshizawa K, Ota M, Tanaka E: Association of serum cytokine levels with treatment response to pegylated interferon and ribavirin therapy in genotype 1 chronic hepatitis $C$ patients. J Infect Dis 2011, 203:1087-1095.

30. Atsukawa M, Nakatsuka K, Kobayashi T, Shimizu M, Tamura H, Harimoto H, Takahashi H, Sakamoto C: Ribavirin down-modulates inducible costimulator on CD4+ T cells and their interleukin-10 secretion to assist in hepatitis C virus clearance. J Gastroenterol Hepatol 2012, 27:823-831.
31. Liu BS, Groothuismink ZM, Janssen HL, Boonstra A: Role for IL-10 in inducing functional impairment of monocytes upon TLR4 ligation in patients with chronic HCV infections. J Leukoc Biol 2011, 89:981-988.

32. Gremion $C$, Cerny $A$ : Hepatitis $C$ virus and the immune system: a concise review. Rev Med Virol 2005, 15:235-268.

33. Rehermann B: Cellular immune response to the hepatitis $C$ virus. J Viral Hepat 1999, 6:31-35.

34. Cohen IR: The cognitive paradigm and the immunological homunculus. Immunol Today 1992, 13:490-494.

35. Atlan $\mathrm{H}$, Cohen IR: Immune information, self-organization and meaning. Int Immunol 1998, 10:711-717.

36. Cohen IR: Biomarkers, self-antigens and the immunological homunculus. J Autoimmun 2007, 29:246-249.

37. Quintana FJ, Cohen IR: The natural autoantibody repertoire and autoimmune disease. Biomed Pharmacother 2004, 58:276-281.

38. Elkon K, Casali P: Nature and functions of autoantibodies. Nat Clin Pract Rheumatol 2008, 4:491-498.

39. Avrameas $S$, Ternynck T, Tsonis IA, Lymberi P: Naturally occurring B-cell autoreactivity: a critical overview. J Autoimmun 2007, 29:213-218.

40. Madi A, Bransburg-Zabary S, Kenett DY, Ben-Jacob E, Cohen IR: The natural autoantibody repertoire in newborns and adults: a current overview. Adv Exp Med Biol 2012, 750:198-212.

doi:10.1186/1476-9255-10-14

Cite this article as: Davtyan et al:: The anti-idiotypic antibody 1F7 stimulates monocyte interleukin-10 production and induces endotoxin tolerance. Journal of Inflammation 2013 10:14.

\section{Submit your next manuscript to BioMed Central and take full advantage of:}

- Convenient online submission

- Thorough peer review

- No space constraints or color figure charges

- Immediate publication on acceptance

- Inclusion in PubMed, CAS, Scopus and Google Scholar

- Research which is freely available for redistribution

Submit your manuscript at www.biomedcentral.com/submit
C Biomed Central 